\title{
Evaluation of Haematological and Biochemical Parameters of Juvenile Oreochromis niloticus after Exposure to Water Soluble Fractions of Crude Oil
}

\author{
ERIEGHA, OJ; OMITOYIN, BO; AJANI, EK
}

\author{
Department of Aquaculture and Fisheries Management, University of Ibadan \\ Authors Addresses: ochukodegreat@yahoo.com; bo.omitoyin@mail.ui.edu; ek.ajani@ui.edu.ng
}

\begin{abstract}
The influence of water soluble fraction of crude oil from Afiesere oil field on water quality components and its consequent effect on haematological and biochemical parameters in juveniles of Oreochromis niloticus were evaluated. After a preliminary determination of the $96 \mathrm{~h}-\mathrm{LC}_{50}$ of crude oil by probit regression was found to be $92.38 \mathrm{mg} / \mathrm{l}$, fish were exposed to 4 sub-lethal concentrations $\left(30,45,60\right.$ and $75 \%$ of the $\mathrm{LC}_{50}$ corresponding to 28 , 41,55 and $69 \mathrm{mg} / \mathrm{l}$ respectively) of the oil and a control. After 84 days of exposure, blood was collected and used in conducting haematological and biochemical analyses. Exposure of water to crude oil caused increased levels in chloride, conductivity, salinity, magnesium, biochemical oxygen demand, chemical oxygen demand, turbidity and Nitrate. The crude oil contaminated water resulted in a significant reduction $(\mathrm{p}<0.05)$ in the values of red blood cells, packed cell volume and haemoglobin. Although no definite trend in the values of computed haematological indices was observed, MCHC, however, decreased with increased concentration. Also, Glucose, ALP, ALT, AST, Urea and creatinine activities of all the affected set of fish, which have been exposed to the crude oil were significantly higher $(\mathrm{p}<0.05)$ in comparison to their respective control. (C) JASEM
\end{abstract}

https://dx.doi.org/10.4314/jasem.v21i6.7

Keywords: Crude oil, Afiesere oil field, blood, toxicity, water quality, Oreochromis niloticus

Crude oil exploration and exploitation in the Niger Delta region of Nigeria has resulted in the continuous exposure of aquatic organisms to crude oil toxicity. Crude oil varies considerably in its toxicity according to its origin and the length of time the product has been exposed to air. In water, crude oil undergoes both physical and chemical processes such as evaporation, dissolution, emulsion, photolysis and biodegradation which generate a water soluble fraction (Pérez-Cadahía et al., 2004). The water soluble fraction (WSF) of crude oil is that small fraction of oil containing components fully or sparingly soluble in water. Since aquatic organisms directly encounter it, WSF plays an important role in the toxicity of crude oil in aquatic environments (Lari et al., 2015).

Toxicity tests allow the determination of effects of xenobiotic compounds, providing direct evidence of the biological responses of organisms to contaminants. Due to the fact that organisms from different species vary in their sensitivity towards chemical substances, it is difficult to set standards for the protection of species with regard to pollutants in the environment. Extrapolation from one species to another is, therefore, difficult if their relative sensitivities are not known (Hedayati et al., 2010). Laboratory investigations concerning the toxicity of oil to freshwater fishes are numerous. However, in most cases, very little information is provided about the water quality condition causing such toxicity. Such information is essential in making comparisons of the relative toxicities of different petroleum products to the aquatic environment. The purpose of the present study was to determine the variations in water quality, haematological and biochemical parameters after exposure of juveniles of Oreochromis niloticus to WSF of crude oil.

\section{MATERIALS AND METHODS}

Healthy juveniles of $O$. niloticus (average weight $=$ $8.6 \pm 0.5 \mathrm{~g}, \mathrm{n}=300$ ) were procured from Alfa Fish Farm, Alakia, both in Ibadan, Oyo State, Nigeria and were transported to the Research Laboratory of the Department Aquaculture and Fisheries Management, University of Ibadan, Ibadan for acclimatization. Crude oil obtained from the Afiesere oil field, near Ughelli in Delta State of Nigeria and was transported to the Department of Chemistry, Faculty of Science, University of Ibadan where water soluble fraction (WSF) of the oil was prepared using Anderson et $^{\mathrm{al}}{ }^{-}$ (1974). A preliminary short-term $(96 \mathrm{~h})$ static toxicity tests were performed to evaluate the toxicity of WSF to $O$. niloticus using Reish and Oshida (1987). The $96 \mathrm{hrs} \mathrm{LC}_{50}$ determined through probit analysis for juveniles of $O$. niloticus after exposure to WSF of crude oil was $92.38 \mathrm{mg} / \mathrm{l}$.

To evaluate the effects of the crude oil on Haematological and Biochemical parameters, fish were exposed to 4 sub-lethal concentrations $(30,45$, 60 and $75 \%$ of the $\mathrm{LC}_{50}$ corresponding to $28,41,55$, $69 \mathrm{mg} / \mathrm{l}$ respectively) and a control group containing clean water in $30 \mathrm{~L}$ experimental tanks containing 20 fish each. All treatments and controls were conducted 
in triplicate. The experimental tanks were filled with $20 \mathrm{~L}$ of the test solution and covered with a lid made of fine polyethylene gauze screen of $1 \mathrm{~mm}$ mesh size to prevent the fish from jumping out of the containers. Experimental fish were fed ad libitum twice daily with a commercial feed containing $42 \%$ Crude Protein. Natural photoperiod was maintained throughout the experiment. The test was performed using a semi-static renewal method in which the exposure medium was exchanged every 3 days to maintain the strength of the toxicant and minimize the level of ammonia. The assay was carried out for 84 days.

At the end of the exposure period, blood samples were withdrawn by caudal puncture, with the help of a needle and syringe from 3 randomly selected fish from each concentration (one fish from every replicate). The withdrawn blood was immediately transferred into small vials containing heparin as anticoagulant and transported to the Department of Veterinary Pathology, University of Ibadan. Red blood cells (RBC) and white blood cells (WBC) were counted in a Neubauer chamber; packed cell volume (PCV) by the microhematocrit technique; and haemoglobin level $(\mathrm{Hb})$ by the cyanomethemoglobin method. Haematological indices were computed using standard formulae. Mean corpuscular volume
(MCV, fl), calculated as $(\mathrm{Hct} \times 10) / \mathrm{RBC}$; mean corpuscular haemoglobin $(\mathrm{MCH}, \mathrm{pg})$, calculated as $(\mathrm{Hb} \times 10) / \mathrm{RBC}$ and mean corpuscular haemoglobin concentration (MCHC, \%) calculated as $(\mathrm{Hb} \times$ 100)/PCV. Total protein, albumin and alanine aminotransferase (ALT) were determined by haemocytometric. Alkaline phosphatase (ALP) level was determined by colourimetry while Urea and Creatinine by diacetyl reaction methods. The RANDOX® kit was used for the determination of the aspartate aminotransferase (AST) while Glucose was measured in the laboratory using an electronic blood glucose meter. Globulin was determined by subtracting albumin from total protein. Data were analysed by using one-way ANOVA and the TukeyHSD multiple comparisons test for post hoc analysis and were expressed as mean \pm SD (standard deviation). The significance level adopted was 95\% $(\mathrm{P}<0.05)$. Statistical analyses were performed using the software SPSS Version 20 (SPSS Inc., Chicago, IL).

\section{RESULTS AND DISCUSSION}

The results of physicochemical characteristics of water samples from the various concentrations of crude oil used for the bioassay in $O$. niloticus is summarized in Table 1.

Table 1: Physicochemical characteristics of water after exposure of $O$. niloticus to WSF of crude oil

\begin{tabular}{|c|c|c|c|c|c|}
\hline \multirow[t]{2}{*}{ Parameter } & \multicolumn{5}{|c|}{$\%$ Concentration of $\mathrm{LC}_{50}$} \\
\hline & 0\% & $30 \%$ & $45 \%$ & $60 \%$ & $75 \%$ \\
\hline pH & $6.89 \pm 0.02^{\mathrm{b}}$ & $6.88 \pm 0.01^{\mathrm{ab}}$ & $6.74 \pm 0.15^{\mathrm{ab}}$ & $6.70 \pm 0.01^{\mathrm{ab}}$ & $6.57 \pm 0.10^{\mathrm{a}}$ \\
\hline Alkalinity $\left(\mathrm{mgCaCO}_{3} / \mathrm{L}\right)$ & $131.00 \pm 1.41^{\mathrm{a}}$ & $130.00 \pm 1.44^{\mathrm{a}}$ & $126.50 \pm 6.36^{\mathrm{a}}$ & $127.50 \pm 3.54^{\mathrm{a}}$ & $127.00 \pm 2.12^{\mathrm{a}}$ \\
\hline Chloride (mg/L) & $7.88 \pm 0.09^{\mathrm{a}}$ & $8.20 \pm 0.08^{\mathrm{ab}}$ & $8.47 \pm 0.11^{\mathrm{bc}}$ & $8.69 \pm 0.07^{\mathrm{cd}}$ & $8.79 \pm 0.06^{\mathrm{d}}$ \\
\hline Conductivity $(\mu \mathrm{homs} / \mathrm{cm})$ & $596.50 \pm 0.71^{a}$ & $606.50 \pm 3.54^{\mathrm{ab}}$ & $620.50 \pm 10.61^{\mathrm{bc}}$ & $631.00 \pm 1.41^{\mathrm{c}}$ & $652.50 \pm 2.12^{\mathrm{d}}$ \\
\hline Salinity (g/kg) & $0.21 \pm 0.01^{\mathrm{a}}$ & $0.26 \pm 0.01^{\mathrm{b}}$ & $0.26 \pm 0.00^{\mathrm{b}}$ & $0.28 \pm 0.01^{\mathrm{b}}$ & $0.31 \pm 0.01^{\mathrm{c}}$ \\
\hline $\begin{array}{l}\text { Total Hardness } \\
\left(\mathrm{mgCaCO}_{3} / \mathrm{L}\right)\end{array}$ & $107.50 \pm 3.54^{\mathrm{a}}$ & $114.50 \pm 0.71^{\mathrm{a}}$ & $124.00 \pm 1.41^{\mathrm{b}}$ & $129.00 \pm 1.41^{\mathrm{bc}}$ & $134.50 \pm 0.71^{\mathrm{c}}$ \\
\hline Calcium $(\mathrm{mg} / \mathrm{L})$ & $40.65 \pm 0.50^{\mathrm{ab}}$ & $42.00 \pm 0.71^{\mathrm{b}}$ & $42.55 \pm 0.64^{\mathrm{b}}$ & $41.25 \pm 0.35^{\mathrm{ab}}$ & $39.75 \pm 0.35^{\mathrm{a}}$ \\
\hline Magnesium (mg/L) & $2.81 \pm 0.07^{\mathrm{a}}$ & $2.99 \pm 0.07^{\mathrm{a}}$ & $3.38 \pm 0.04^{\mathrm{b}}$ & $3.61 \pm 0.09^{\mathrm{bc}}$ & $3.91 \pm 0.08^{\mathrm{c}}$ \\
\hline Total Dissolved Solids (mg/L) & $323.00 \pm 5.66^{\mathrm{c}}$ & $316.00 \pm 2.83^{\mathrm{c}}$ & $293.00 \pm 4.24^{\mathrm{b}}$ & $280.50 \pm 6.36^{\mathrm{ab}}$ & $265.50 \pm 4.95^{\mathrm{a}}$ \\
\hline Total Solids (mg/L) & $507.50 \pm 3.54^{\mathrm{a}}$ & $546.00 \pm 5.66^{\mathrm{b}}$ & $779.00 \pm 15.56^{\mathrm{e}}$ & $710.00 \pm 1.41^{\mathrm{d}}$ & $620.50 \pm 6.36^{\mathrm{c}}$ \\
\hline $\begin{array}{c}\text { Biochemical Oxygen Demand } \\
(\mathrm{mg} / \mathrm{L})\end{array}$ & $7.99 \pm 0.15^{\mathrm{a}}$ & $9.60 \pm 0.14^{\mathrm{b}}$ & $10.65 \pm 0.21^{\mathrm{c}}$ & $11.40 \pm 0.14^{\mathrm{d}}$ & $11.85 \pm 0.07^{\mathrm{d}}$ \\
\hline $\begin{array}{c}\text { Chemical Oxygen Demand } \\
\text { (mg/L) }\end{array}$ & $110.50 \pm 3.54^{\mathrm{a}}$ & $209.00 \pm 8.49^{\mathrm{b}}$ & $216.00 \pm 8.49^{\mathrm{b}}$ & $230.00 \pm 1.41^{\mathrm{b}}$ & $255.00 \pm 4.24^{\circ}$ \\
\hline Turbidity (FTU) & $3.88 \pm 0.04^{\mathrm{a}}$ & $6.05 \pm 0.35^{\mathrm{b}}$ & $7.32 \pm 0.45^{\mathrm{bc}}$ & $8.25 \pm 0.35^{\mathrm{c}}$ & $9.69 \pm 0.27^{\mathrm{d}}$ \\
\hline Nitrate $(\mathbf{m g} / \mathbf{L})$ & $2.46 \pm 0.42^{\mathrm{a}}$ & $4.75 \pm 0.34^{\mathrm{b}}$ & $6.02 \pm 0.40^{\mathrm{b}}$ & $7.60 \pm 0.28^{\mathrm{c}}$ & $8.74 \pm 0.27^{\mathrm{c}}$ \\
\hline Sulphate $(\mathbf{m g} / \mathbf{L})$ & $9.30 \pm 0.13^{\mathrm{c}}$ & $9.49 \pm 0.02^{\mathrm{c}}$ & $8.43 \pm 0.11^{\mathrm{b}}$ & $7.85 \pm 0.35^{\mathrm{ab}}$ & $7.05 \pm 0.21^{\mathrm{a}}$ \\
\hline Phosphate $(\mathrm{mg} / \mathrm{L})$ & $1.23 \pm 0.02^{\mathrm{a}}$ & $1.31 \pm 0.01^{\mathrm{a}}$ & $1.25 \pm 0.06^{\mathrm{a}}$ & $1.26 \pm 0.01^{\mathrm{a}}$ & $1.20 \pm 0.03^{\mathrm{a}}$ \\
\hline
\end{tabular}

Alkalinity, phosphate, calcium, total solids and sulphate levels showed an irregular trend across concentration of the oil. However, alkalinity and phosphate readings revealed no significant differences $(\mathrm{P}>0.05)$. Chloride, conductivity, salinity, magnesium, biochemical oxygen demand
(BOD), chemical oxygen demand (COD), turbidity and Nitrate levels increased with increase in the volume of crude oil introduced in culturing systems. A sharp increase in COD levels was observed upon the introduction of crude oil as control as control had $110.50 \pm 3.54 \mathrm{mg} / \mathrm{l}$ whereas minimum concentration 
had $209.00 \pm 8.49 \mathrm{mg} / \mathrm{l}$. Also, BOD levels in the various test solutions were significantly $(\mathrm{P}<0 \quad .05)$ higher than BOD levels of the control experiment. Chattopadhyay et al (1988) indicated $10-20 \mathrm{mg} / 1$ as the optimum BOD range for fish culture in effluent or polluted waters. The addition of significant quantities of crude oil to any water body causes an immediate rise in the BOD due to the activities of hydrocarbon degraders and the blockade of oxygen dissolution. This observation supports earlier reports of Baden (1982) that a corresponding increase in biological oxygen demand and a decrease in dissolved oxygen content are typical of water bodies contaminated with crude oil. A similar increase in BOD levels with increasing concentration of WSFs of crude oil has also been reported by Nwabueze and Agbogidi (2010). Total solids, pH and sulphate levels decreased with increase in the concentration of crude oil. The $\mathrm{pH}$ of the water was within the FEPA acceptable range of 6.0 to 9.0 for the sustenance of aquatic life and may unlikely contribute to the toxicity of the water soluble fraction. The decreased in $\mathrm{pH}$ value as concentration increases observed in this study is in agreement with the findings of Giari et al (2012) that reported a decrease in $\mathrm{pH}$ level after a spill. Although, Obasohan et al (2011) have reported that WSFs of crude oil did not affect the $\mathrm{pH}$ of water as a value of 6.5 was noted across all levels of exposure.

The results of haematological and plasma biochemical parameters of $O$. niloticus following exposure to sub-lethal concentrations of crude oil are shown in tables 2 and 3 respectively

Table 2: Haematological parameters of $O$. niloticus following exposure to sub-lethal concentrations of crude oil. Data are means \pm S.D $(n=3)$.

\begin{tabular}{|c|c|c|c|c|c|}
\hline \multirow[t]{2}{*}{ Parameters } & \multicolumn{5}{|c|}{$\%$ Concentration $\mathbf{L C}_{50}$} \\
\hline & $0 \%$ & $30 \%$ & $45 \%$ & $60 \%$ & $75 \%$ \\
\hline $\operatorname{PCV}(\%)$ & $23.67 \pm 0.58^{b}$ & $22.00 \pm 1.00^{\mathrm{b}}$ & $19.67 \pm 0.58^{\mathrm{a}}$ & $19.33 \pm 1.15^{\mathrm{a}}$ & $18.33 \pm 0.58^{\mathrm{a}}$ \\
\hline Hb $(g / L)$ & $7.03 \pm 0.42^{\mathrm{d}}$ & $7.03 \pm 0.41^{\mathrm{c}}$ & $6.03 \pm 0.15^{\mathrm{b}}$ & $5.87 \pm 0.15^{\mathrm{ab}}$ & $5.03 \pm 0.41^{\mathrm{a}}$ \\
\hline WBC $\left(\times 10^{3} \mu \mathrm{l}\right)$ & $15.63 \pm 0.06^{\mathrm{c}}$ & $15.00 \pm 0.10^{\mathrm{bc}}$ & $14.87 \pm 0.06^{\mathrm{b}}$ & $15.03 \pm 0.42 b^{c}$ & $14.03 \pm 0.41^{\mathrm{a}}$ \\
\hline $\operatorname{MCV}(\mathbf{f L})$ & $176.60 \pm 3.29^{\mathrm{a}}$ & $203.77 \pm 11.14^{\mathrm{c}}$ & $120.65 \pm 2.93^{\mathrm{a}}$ & $207.82 \pm 8.67^{\mathrm{c}}$ & $163.70 \pm 5.34^{\mathrm{b}}$ \\
\hline
\end{tabular}

Table 3: Biochemical alterations in O. niloticus following exposure to sub-lethal concentrations of crude oil Data are means \pm S.D $(n=3)$.

\begin{tabular}{cccccc}
\hline Parameter & \multicolumn{5}{c}{ \% Concentration of LC $\mathbf{C C}_{\mathbf{5 0}}$} \\
& $\mathbf{0 \%}$ & $\mathbf{3 0 \%}$ & $\mathbf{4 5 \%}$ & $\mathbf{6 0 \%}$ & $\mathbf{7 5 \%}$ \\
\hline Glucose $(\mathrm{mg} / \mathrm{dl})$ & $186.33 \pm 0.58^{\mathrm{a}}$ & $216.67 \pm 7.63^{\mathrm{b}}$ & $217.33 \pm 18.72^{\mathrm{b}}$ & $237.67 \pm 3.78 \mathrm{~b}^{\mathrm{c}}$ & $255.67 \pm 7.23^{\mathrm{c}}$ \\
Total Protein $(\mathrm{mg} / \mathrm{dl})$ & $7.33 \pm 0.57^{\mathrm{d}}$ & $5.83 \pm 0.29^{\mathrm{c}}$ & $5.17 \pm 0.29^{\mathrm{bc}}$ & $4.83 \pm 0.46^{\mathrm{b}}$ & $3.96 \pm 0.15^{\mathrm{a}}$ \\
Albumin $(\mathrm{mg} / \mathrm{dl})$ & $2.43 \pm 0.06^{\mathrm{d}}$ & $2.07 \pm 0.05^{\mathrm{c}}$ & $1.60 \pm 0.11^{\mathrm{b}}$ & $1.17 \pm 0.15^{\mathrm{a}}$ & $0.95 \pm 0.05^{\mathrm{a}}$ \\
Globulin $(\mathrm{mg} / \mathrm{dl})$ & $4.90 \pm 0.61^{\mathrm{b}}$ & $3.77 \pm 0.32^{\mathrm{a}}$ & $3.57 \pm 0.21^{\mathrm{a}}$ & $3.67 \pm 0.42^{\mathrm{a}}$ & $2.88 \pm 0.29^{\mathrm{a}}$ \\
ALP & $182.00 \pm 1.00^{\mathrm{a}}$ & $183.33 \pm 0.58^{\mathrm{a}}$ & $185.00 \pm 1.00^{\mathrm{a}}$ & $199.67 \pm 0.57^{\mathrm{b}}$ & $208.63 \pm 3.21^{\mathrm{c}}$ \\
Urea (mg/dl) & $8.50 \pm 0.10^{\mathrm{a}}$ & $8.67 \pm 0.06^{\mathrm{ab}}$ & $8.87 \pm 0.33^{\mathrm{bc}}$ & $8.90 \pm 0.10^{\mathrm{c}}$ & $8.67 \pm 0.06^{\mathrm{ab}}$ \\
ALT & $23.67 \pm 0.58^{\mathrm{a}}$ & $25.67 \pm 0.05^{\mathrm{a}}$ & $30.33 \pm 1.52^{\mathrm{b}}$ & $36.33 \pm 1.15^{\mathrm{c}}$ & $38.67 \pm 0.58^{\mathrm{c}}$ \\
AST & $183.67 \pm 0.58^{\mathrm{a}}$ & $186.00 \pm 1.73^{\mathrm{a}}$ & $186.67 \pm 2.31^{\mathrm{a}}$ & $194.00 \pm 1.00^{\mathrm{b}}$ & $197.00 \pm 1.00^{\mathrm{b}}$ \\
Creatinine (mg/dl) & $0.33 \pm 0.04^{\mathrm{a}}$ & $0.37 \pm 0.02^{\mathrm{a}}$ & $0.45 \pm 0.03^{\mathrm{b}}$ & $0.52 \pm 0.02^{\mathrm{b}}$ & $0.60 \pm 0.02^{\mathrm{c}}$ \\
\hline Different letters indicate significant difference mean values among treatments (P<0.05). & & &
\end{tabular}

A significant $(\mathrm{p}<0.05)$ reduction in the values of red blood cells, packed cell volume and haemoglobin was observed. Changes in the above haematological parameters might have been influenced by the crude oil. The decrease in RBC has been attributed to haemolysis resulting in haemodilution (Smith et al., 1979). The PCV value of all fish exposed to the crude oil was lower than the reference value for healthy fish provided by Etim et al (2009). The observed decrease in PCV value after exposure to the crude oil may be due to the less oxygen content in the blood of $O$. niloticus. Also, reduction in haemoglobin content in exposed fish relative to control signifies that the fish's ability to provide sufficient oxygen to the tissues is restricted considerably and will result in a decrease of physical activity (Kori-Isiakpere et al., 2009). Although no absolute pattern of changes in the values of computed $\mathrm{MCV}$ and $\mathrm{MCH}$, decrease in MCHC value as the concentration of crude oil increases was however observed. 
The mean plasma Glucose, ALP, ALT, AST, Urea and creatinine activities of all the affected set of fish, which have been exposed to sub-lethal concentrations of crude oil were significantly higher $(\mathrm{p}<0.05)$ in comparison to their respective control. Al-Kindi et al (1996) have also observed significant elevated plasma glucose concentrations after $3 \mathrm{~h}$ exposure to water soluble fraction of crude oil and an increase of over $50 \%$ after $48 \mathrm{~h}$ in Pleuronectes flesus. The upsurge in the activity of these enzymes assessed in this study reflects a direct alteration in the hepatic structural integrity (Lin et al., 2002). Elevation of the serum urea and creatinine may be attributed to kidney disorder (Zaki et al., 2009). The Increased levels of urea observed in this study could be as a result of impaired kidney function, liver diseases and cardiac arrest (Abdelmoneim et al., 2008). A significant $(\mathrm{p}<0.05)$ reduction in values of total protein, albumin and globulin was observed as the concentration of WSF of crude oil increases. Reduction in total protein content may be as a result of the breakdown of protein into free amino acids under the effect of crude oil exposure. Similar depletion in protein content has been reported by Rostam and Soltani (2016) after exposure of Acipenser persicus to crude oil. The reduced globulin levels observed in this study may to a disruption in protein biosynthesis (Banaee and Ahmadi, 2011).

Conclusion: The results of this study have demonstrated that sublethal concentrations of WSF of crude oil can pose undesirable changes in water quality. The crude oil influenced water quality can, therefore, induce a variety of alterations on haematological and biochemical parameters in juveniles of $O$. niloticus. The implications of these results include adverse deterioration in the health status of fish after a prolonged exposure with direct bearing on growth, disease resistibility and survivability. Since genotoxicity test is often more sensitive than the endpoints of pathology, future studies are required in order to investigate the effects of sublethal concentrations of WSF of crude oil at the molecular level.

\section{REFERENCES}

Abdelmoneim, A; AbouShabana, N; Khadre S; Abdel, K (2008). Physiological and histopathological effects in cat fish (Clarias lazera) exposed to dyestuff and chemical water. Inter. J. Zool. Res. 4(4): 189-202.

Al-kindi, AYA; Brown, JA; Waring, CP; Collins, JE (1996). Endocrine, osmoregulatory, respiratory and haematological parameters in flounder exposed to the water soluble fraction of crude oil. Journal of Fish Biology. 49: 1291-1305.

Anderson, JW; Neff, JM; Cox, BA; Tatem, HE; Hightower, GM (1974). Characteristics of Dispersions and Water-Soluble Extracts of Crude and Refined Oils and Their Toxicity to Estuarine Crustaceans and Fish. Marine Biology. 27: $75-88$.

Baden, P (1982). Oxygen consumption rate of shrimp exposed to crude oil extract. Marine Pollution Bulletin. 13(7): 230-233.

Banaee, M; Ahmadi, K (2011). Sub-lethal toxicity impacts of endosulfan on some biochemical parameters of the freshwater crayfish (Astacus leptodactylus). Res J Environ Science 5(11): 827-835.

Chattopadhyay, GN; Saha, PK; Gosh, A; Karmakar, HC (1988). A Study on Optimun BOD Levels for Fish Culture in Wastewater Ponds. Biological Wastes. 25(2): 79-85.

Etim, L; Olele, FN; Eriegha, OJ (2009). Blood characteristics of Oreochromis niloticus (Nile Tilapia) from Ona Lake, Asaba, Nigeria. African Journal of Environmental Pollution \& Health. 7(1): 43-46.

Giari, L; Dezfuli, BS; Lanzoni, M; Castaldelli, G (2012). The impact of an oil spill on organs of bream Abramis brama in the Po River. Ecotoxicology \& Environmental Safety 77: 1827.

Hedayati, A; Safahieh, A; Savari, A; Marammazi, JG (2010). Detection of Range Finding Test of Mercury Chloride in Yellowfin Sea Bream (Acanthopagrus latus). Iranica Journal of Energy \& Environment 1 (3): 228-233.

Kori-Siakpere, O; Ogbe, MG; Ikomi, RB (2009). Haematological response of the African catfish: Clarias gariepinus (Burchell, 1822) to sub-lethal concentrations of potassium permanganate. Scientific Research \& Essay. 4(5): 457-466.

Lari, B; Abtahi, B; Hashtroudi, MS; Døving, LK (2015). The effect of sublethal concentrations of the water-soluble fraction of crude oil on the chemosensory function of Caspian roach, Rutilus 
caspicus. Environmental Toxicology \& Chemistry 34(8): 1826-1832

Lin, SC; Chung, TC; Ueng, TH; Lin, YH; Hsu, SH; Chiang, CL; Lin, CC (2002). The hepatoprotective effects of solnum alatam moench on acetaminophen-induced hepatoxicity in mice. AM.J. Uin. Med. 28:105-114.

Nwabueze, AA; Agbogidi, OM (2010). Impact of water soluble fractions of crude oil On growth performance of the catfish Heterobrancuhus bidorsalis. ARPN Journal of Agricultural \& Biological Science. 5(1): 43-46.

Obasohan, EE; Oronsaye, JAO; Obano, EE (2011). Growth responses of fingerlings of the African mudfish; Parachanna obsura to water soluble fractions of crude oil. African Scientist. 12(1): 13-17.

Pérez-Cadahía, B; Laffon, B; Pásaro, E; Méndez, J (2004). Evaluation of PAH bioaccumulation and DNA damage in mussels (Mytilus galloprovincialis) exposed to spilled Prestige crude oil. Comp Biochem. Physiol. 138:453-460.

Reish, DL; Oshida, OS (1987). Manual of Methods in aquatic environment research. Part 10. Shortterm static bioassays. FAO Fisheries Technical Paper No 247. Rome.62 pages

Rostam, HAK; Soltani, M (2016). The effect of chronic crude oil exposure on some hematological and biochemical parameters of juvenile Beluga (Husohuso Linnaeus, 1758). International Journal of Aquatic Science. 7(2): 73-86.

Smith, GL; Hattingh, J; Burger, AP (1979). Haematological assessment of anaesthesia, MS 222 in natural and neutral forming three freshwater fish species: inter-specific differences. J. Fish Biol. 15: 633-643.

Zaki, M; Moustafa, S; Fawzi, O; Khafagy, M; Bayumi, F (2009). Clinicopathological, Biochemical and Microbiological Change on Grey Mullet Exposed to Cadmium Chloride. American-Eurasian J. Agric. \& Environ. Sci. 5 (1): 20-23. 